\title{
Den internationale retsorden under pres
}

\section{Tyge Lehmann}

Folkeretten har sine vanskeligheder, når det gæelder magtanvendelse og væbnede konflikter. Til gengæld fungerer folkeretten på en lang række civile områder. Og hensynet til menneskerettigheder er voksende

International retsorden? Har vi overhovedet sådan én? Sidder retten ikke i spydstagen, og er det mon ikke de politiske hensyn - i første række af sikkerhedsmæssig og økonomisk karakter - der bliver afg $\varnothing$ rende, når staterne skal træffe beslutninger i internationale spørgsmål?

Retlige betragtninger som $\mathrm{x}$ folkerettens forbud imod magtanvendelse kan vist ikke trumfe et realpolitisk ønske hos en stat om at bruge magt for at fremme sine egne interesser? Eller sagt på en anden måde: udviklingen styres vel efter den velkendte maksime: Politik er det muliges kunst, succes dens eneste norm, takt og magt dens midler.

Ja, sådan kan det unægtelig se ud, når man ser sig om i verden især si- den den 11. september 2001. Men det er for pessimistisk et udsyn. Folkeretten er nok under pres især som følge af kampen imod den omsiggribende internationale terrorisme, men opbygningen af en international retsorden har gjort markante fremskridt siden FN-pagtens ikrafttræden den 24. oktober1945. Jeg har selv haft mulighed for at tage aktivt del i dette arbejde siden 1972, hvor jeg første gang repræsenterede Danmark i FN-generalforsamlingens seks (juridiske) udvalg. I 1995 havde jeg den ære at være formand for udvalget under generalforsamlingens 50 års jubilæum.

Som jeg har oplevet det, er udviklingen i den globale internationale retsorden blevet præget af nogle centrale udenrigspolitiske begiven- 
heder - først og fremmest oprettelsen af De Forenede Nationer i 1945, hvor de grundlæggende og stadig gældende principper for staternes samarbejde til fremme af fred og fremskridt er fastlagt.

Foruden grundsætningerne om ikke-anvendelse af magt og bilæggelse af uoverensstemmelser mellem staterne ved fredelige midler indeholder FN-pagten et pålæg om at støtte den fremadskridende udvikling af folkeretten og kodifikationen af den. Dette arbejde har fra starten været centreret i FN's Folkeretskommission og har resulteret i nedskrivning og vedtagelse af en række grundlæggende traktater om bl.a. diplomaters og konsulers retsstilling, om staters immunitet, om retsordenen på havene, om indgåelse af traktater, om staters ansvar, om bekæmpelse af international terrorisme, om statssuccession, m.m. Hertil slutter sig en lang række af traktater og konventioner inden for nedrustning, menneskerettigheder, miljøbeskyttelse, arbejdsretlige spørgsmål, krigens folkeret og meget mere. Det er således ikke den retlige regulering af staternes optræden det skorter på, men reglernes implementering i praksis.

Selv i den Kolde Krigs periode lod det sig gøre at udforme et omfattende regelgrundlag, så længe der ikke tilføjedes bindende regler om en uafhængig kontrol med staternes overholdelse af de påtagne forpligtelser!
Med Berlinmurens fald og ophøret af den Kolde Krig i efteråret 1989 skete der en markant ændring i holdningen til spørgsmålet om iværksættelse af en mere effektiv håndhævelse af folkeretten bl.a. gennem etablering af internationale straffedomstole, et projekt som havde stået stille siden krigsforbryderprocesserne i Nürnberg og Tokyo umiddelbart efter afslutningen af Anden Verdenskrig. Oprettelsen af en stilling som FN-højkommissær for Menneskerettigheder havde i den Kolde Krigs periode stået som et fatamorgana, men så efter koldkrigen dagens lys. Mere herom nedenfor.

Så kom terrorangrebet den 11 . september, og 'krigen' mod den internationale terrorismes netværk indledtes og satte dele af den internationale retsorden under et nyt pres. Dette emne vil blive taget op nedenfor under denne overskrift. Men først en oversigt over udviklingen siden 1945 .

\section{National kontra international ret}

Ligesom vores grundlov udgør den overordnede retligt bindende ramme for samfundslivet i Danmark, er FN-pagten den retligt bindende traktat for de i dag 192 medlemsstaters indbyrdes forhold.

Inden for grundlovens rammer er samfundslivet reguleret på kryds og tværs med en meget høj detaljeringsgrad, og hvad vigtigst er med 
en betydelig sikkerhed for, at de vedtagne love og administrative bestemmelser bliver overholdt af borgerne - dels på grund af den solidaritet som hersker i samfundet, dels som følge af det magtapparat i form af domstole og politi, som i givet fald kan sikre, at de trufne beslutninger bliver håndhævet.

Ingen borger har nødigt at tage sig selv til rette. Tværtimod er individuel magtanvendelse forbudt. Uoverensstemmelser må i sidste instans løses ad rettens vej. Retlige betragtninger, herunder risikoen for at blive sagsøgt, bliver et væsentlig hensyn, når der skal træffes beslutninger både på det privatretlige plan og i offentligt regi gennem lovgivning og administrative foranstaltninger.

Så effektivt fungerer det internationale samfund af stater ikke. Sammenholdet imellem staterne har endnu ikke udviklet en sådan grad af solidaritet og institutionsopbygning i form af fælles lovgivning, domstole og politimyndighed, der kan formå staterne til helt at afstå fra at tage retten i egen hånd, når de vel at mærke er besiddelse af magtmidlerne dertil. I FN-pagten har vi imidlertid kimen til et internationalt samfund baseret på 'the rule of law'.

Ifølge pagten er magtanvendelse forbudt og staterne forpligter sig til at bilægge deres uoverensstemmelser ved fredelige midler, herunder ved benyttelse af retlige procedurer. FN-pagten kan ses som det interna- tionale samfunds grundlov. Organisationens institutioner tæller generalforsamlingen, der kan lignes ved et debatterende parlament, hvor alle 192 medlemsstater er repræsenteret; Sikkerhedsrådet med 15 medlemmer der har en regeringslignende udøvende funktion; samt en dømmende magt repræsenteret ved Den Internationale Domstol i Haag, bestående af 15 uafhængige dommere.

\section{Juridisk bindende eller ej?}

Generalforsamlingens beslutninger er imidlertid ikke juridisk bindende for staterne. Det er til gengæld Sikkerhedsrådets beslutninger, om end kun inden for det yderst begrænsede område der vedrører trusler mod freden, fredsbrud og angrebshandlinger (pagtens kap. VII ). Hvad endelig angår domstolen i Haag, er retsplejen frivillig i den forstand, at kun de stater der udtrykkeligt har accepteret domstolens myndighed (jurisdiktion), er bundet af dens afgørelser i konkrete tvister, hvori de pågældende stater er parter.

I øjeblikket har kun omkring en tredjedel af medlemsstaterne på forhånd accepteret domstolens myndighed. Til dem hører naturligvis Danmark. For de mindre ikke-magtfulde stater må det være en klar interesse at slå til lyd for den fredelige retsvej til løsning af internationale konflikter. I fire tilfælde har domstolen i Haag truffet afgørelse i sager, 
hvor Danmark har været part: Østgrønlandsagen fra 1933 mellem Danmark og Norge; Nordsøsokkelsagen fra 1969 mellem Danmark / Holland og Forbundsrepublikken Tyskland; Storebæltsagen fra 1991 mellem Finland og Damark; Jan Mayen-sagen fra 1993 mellem Danmark og Norge (om afgrænsningen af farvandet mellem Østgrønland og den norske $\varnothing$ Jan Mayen ). I de to sidstnæunte sager varetog jeg hvervet som leder af de danske procesdelegationer.

Derimod er det en trist kendsgerning, at blandt Sikkerhedsrådets fem faste medlemmer - Frankrig, Kina, Rusland, Storbritannien og USA - er det alene Storbritannien, der har accepteret domstolens jurisdiktion. De øvrige fire faste medlemmer er ikke desto mindre repræsenteret i domstolen med hver sin dommer på lige fod med Storbritannien.

Det er et dårligt signal at sende til den øvrige kreds af FN-medlemsstater, især når det i pagtens art. 36 er fastsat, at Sikkerhedsrådet i sine bestræbelser for at opretholde international fred og sikkerhed til stadighed bør holde sig for øje, at retstvister staterne imellem som hovedregel af parterne bør henvises til afgørelse ved Den Internationale Domstol i Haag.

Den manglende opslutning bag domstolens virke fra de nævnte fire faste medlemmers side bidrager ikke til en styrkelse af den internationale retsorden. På trods heraf tegner der sig alligevel en klar tendens blandt staterne til i højere grad at betjene sig af domstolen i Haag til endelig afgørelse af mangeårige udestående konflikter. Det gælder især sager om afgrænsning af landog havterritorier. Således har eksempelvis Honduras og El Salvador, Libyen og henholdsvis Malta og Chad, Nigeria og Cameroun, Qatar og Bahrain, Indonesien og Malaysia samt senest Ukraine og Rumænien alle fået langvarige grænsekonflikter endeligt afgjort ved domstolen og, ikke uvæsentligt, har efterlevet afgørelserne frivilligt.

Hvad angår FN-pagtens magtanvendelsesforbud (art. 2) brydes dette alene af retten til individuelt og kollektivt selvforsvar (art. 51) og modsvares af Sikkerhedsrådets beføjelse til at bruge eller bemyndige magtanvendelse i tilfælde af fredsbrud eller trusler herom.

Rådets kollektive retshåndhævelsessystem er imidlertid skrøbeligt som følge af den indbyggede vetoret hos rådets faste medlemmer. Baggrunden herfor er naturligvis den realpolitiske betragtning, at iværksættelse af magtmidler over for en af de fem stormagter eller imod en af disses ønsker i stedet for at forhindre krig snarere vil udløse én.

FN-pagten er et både meget idealistisk, men i høj grad også et realistisk dokument. Det gælder magtanvendelsesforbudet såvel som den højt besungne nationale suverænitet, der kommer til udtryk i pagtens 
art. 7 om forbuddet imod at gribe ind i en medlemsstats indre anliggender.

\section{Ny status for overvågning}

Medens retsplejens frivillighed og vetorettens indførelse kan siges at fungere som en kærkommen ventil for stormagterne til ikke at blive bragt i gabestokken, en art retlig særstatus i forhold til hele den øvrige medlemskreds, som det vil være svært at bryde, så er forbeholdet for indre anliggender med tiden kommet under et massivt pres. Det gælder specielt i relation til kritik af menneskerettighedssituationen i et medlemsland.

Medens det holdt hårdt at komme igennem med en sådan kritik i den Kolde Krigs periode, så har Berlinmurens fald åbnet op for sluserne på dette politikområde.

Et markant gennembrud fandt sted på FN's Verdenskonference om Menneskerettigheder i Wien, 1993. I konferencens slutdokument fastslås det for første gang $\mathrm{i}$ en global sammenhæng med samtlige medlemslandes indforståelse, at fremme af respekten for alle menneskerettigheder overalt i verden er en legitim opgave for det internationale samfund.

Samtidig lagde konferencen grunden til oprettelse af en stilling som FN-højkommissær for Menneskerettigheder, en post som formelt blev vedtaget under den efterfølgende
48. FN-generalforsamling i New York. Som indehaver af EU-formandskabet under Wien-konferencen blev det en særlig opgave for Danmark at bringe højkommissærprojektet tørskoet i land, hvilket altså lykkedes til manges overraskelse.

Det er en af højkommissærens vigtigste opgaver at føre en aktiv og konstruktiv dialog med FN's medlemslande, og naturligvis især med de lande, der har svært ved at overholde menneskerettighederne. Forbeholdet for indre anliggender opretholdes dog fortsat, når det kommer til beslutninger om at gennemføre undersøgelse af menneskerettighedssituationen i et bestemt land inden for dettes egne grænser.

Staterne kan således nægte at lade en af menneskerettighedsrådets specialrapportører rejse ind i landet og foretage uafhængige undersøgelser på stedet. Hertil kræves, at situationen har udviklet sig til et fredsbrud eller en trussel mod freden således, at Sikkerhedsrådet i medfør af pagtens kap.VII kan vedtage tvangsforanstaltninger over for det pågældende land, herunder fx udsendelse af en fact-finding mission eller iværksættelse af en direkte humanitær intervention med anvendelse af militære magtmidler.

Dette er tidligere sket med Sikkerhedsrådets billigelse i relation til Somalia og Bosnien, hvor rådet har fortolket trusselsbegrebet i kap. VII udvidende til også at omfatte chokerende humanitære tilstande. 
I relation til situationen i Kosovo i foråret 1999 er en gruppe af stater NATO-landene - gået så vidt som til at gennemføre en humanitær intervention uden om den retlige ramme som udgøres af FN-pagten, idet den militære aktion fandt sted uden Sikkerhedsrådets godkendelse, angiveligt fordi Rusland forventedes at nedlægge veto, hvis sagen formelt blev forelagt rådet. Synspunktet var, at det internationale samfund ikke kan nøjes med at se passivt til, når der foregår grove og vedvarende krænkelser af menneskerettighederne. Og hvis Sikkerhedsrådet ikke kan eller vil løfte sit primære ansvar for opretholdelse af international fred og sikkerhed må andre jo forsøge at gøre det. Eller må de?

Det er selvsagt yderst kontroversielt at foretage humanitære interventioner uden enighed mellem Sikkerhedsrådets fem faste medlemmer. Og det gælder også, selvom man omformer interventionsbegrebet, der jo har en lidt dubiøs klang, til det bedre klingende: ansvar for beskyttelse af personer mod folkedrab, etnisk udrensning og andre forbrydelser mod menneskeheden, også kaldet responsibility to protect.

Forhåbentlig vil Sikkerhedsrådet fremover vide at kende sin besøgelsestid over for optræk til menneskeskabte humanitære katastrofer og agere i fællesskab med den styrke, det giver til afværgelse af sådanne katastrofer og til yderligere fastlæggelse af grænserne for, hvad det in- ternationale samfund vil acceptere fra egenrådige magthaveres side.

\section{Berlinmurens fald}

Medens det som nævnt stod relativt sløjt til med den effektive håndhævelse af folkeretten under den Kolde Krig - når bortses fra Korea-aktionen i 1950-53, hvor aktionen imod den nordkoreanske aggression blev muliggjort, fordi Sovjetunionen i protest var udeblevet fra de afgørende møder i Sikkerhedsrådet - så har udviklingen i den retning taget fart efter Berlinmurens fald. Det gælder ikke mindst FN's Sikkerhedsråd, der for alvor er kommet på banen fra og med den første Golf-krig i 1990-91 og ihærdigt søger at leve op til den rolle som rådet er tiltænkt i FN-pagten - en rolle der måske bedst kan sammenlignes med sejladsen mellem Skylla og Charybdis.

Et yderligere gennembrud kom som nævnt med oprettelsen af stillingen som FN-højkommissær for Menneskerettigheder samt etablering af de særlige straffedomstole til retsforfølgning af personer, der har begået krigsforbrydelser, folkedrab, etniske udrensninger og andre forbrydelser imod menneskeheden i henholdsvis det tidligere Jugoslavien (1993) og Rwanda (1994). Yderligere straffedomstole er etableret i relation til de tidligere konflikter i Sierra Leone og Cambodja.

I 1998 oprettedes den Permanente Internationale Straffedomstol i 
Haag (ICC) til retsforfølgning af personer, der er tiltalt for at have begået nogle af de mest alvorlige forbrydelser som nævnt ovenfor, uanset hvor i verden og af hvem de måtte være begået. Som bekendt har ICC netop indledt sin første straffesag mod en af krigsherrerne fra Congo (DRC) og for nylig har samme domstol udstedt en arrestordre mod Sudans præsident. Diktatorernes tid er - forhåbentlig - ved at rinde ud.

\section{Er FN-pagten tidssvarende?}

I det foregående er der mest fokuseret på det pres, som den internationale retsorden er stillet overfor med henblik på at lukke det berømte 'implementation gap' mellem de efterhånden mange folkeretlige regler og håndhævelsen af dem i praksis. Der er utvivlsomt et stigende pres i offentligheden for, at de internationale aktører, staterne og de relevante FN-organer, optræder mere proaktivt og til fulde benytter deres beføjelser til fordel for ofrene for krænkelser af menneskerettighederne, det være sig i fredstid eller under væbnede konflikter.

I utålmodig afventning af, at de demokratiske kræfter i verdenssamfundet får større gennemslagskraft, er der fremkommet tanker om evt. at erstatte FN med en organisation af demokratiske stater, der kan sætte og implementere en mere progressiv dagsorden for verdenssamfundets videre udvikling i overensstem- melse med den demokratiske retsstats principper. Det vil i mine øjne alene føre til større splittelse og konfrontation mellem staterne. En demokratisk udvikling i verdenssamfundet fremmes bedst inden for den globale ramme, som FN-organisationen repræsenterer, og som er baseret på princippet om universalitet.

Det er inden for denne ramme, hvor alle stater er til stede, at kampen for de demokratiske værdier har størst udsigt til at bære frugt. I FN arbejdes der i mange landegrupperinger - de nordiske lande, EUkredsen, udviklingslandene, de alliancefri lande, gruppen af islamiske lande og andre landegrupperinger og der er selvsagt intet i vejen for, at en gruppe af demokratiske lande samarbejder om fremlæggelse og gennemførelse af forslag, der søger at fremme de demokratiske værdier.

Noget andet er, at man kunne ønske sig, at FN's Sikkerhedsråd havde en bredere repræsentation end de nuværende 15 medlemsstater og dermed en større legitimitet i forhold til den øvrige 192 lande store medlemskreds. Drøftelser herom har stået på i mange år - hidtil uden resultat. De nuværende fem faste medlemmer er ikke meget for at mindske deres privilegerede status, og tilføjelse af yderligere faste medlemmer med vetoret vil utvivlsomt svække rådets effektivitet; selv uden tildeling af yderligere vetoret vil mulighederne for at optræde i enighed blive vanskeliggjort. 


\section{1. september 2001}

I november 1989 proklamerede FN's generalforsamling et Folkeretstiår 1990-1999 med det formål at fremme respekten for folkeretten gennem udbredelse af kendskabet til dette retssystem samt at bidrage til videreudviklingen heraf, bl.a. gennem øget benyttelse af Den Internationale Domstol i Haag og andre mekanismer til fredelig bilæggelse af tvister mellem staterne.

Der var ikke forudset noget specifikt projekt, som skulle søsættes i løbet af 10-året og det skete heller ikke. Men over en bred front som opridset i det foregående drog udviklingen af den internationale retsorden stor nytte af den Kolde Krigs ophør, der tilfældigvis faldt sammen med proklameringen af Folkeretstiåret.

Optimismen bredte sig - i hvert fald hos undertegnede - op mod århundredeskiftet. Nu skulle the rule of law i modsætning til vilkårlig magtudøvelse sættes i førersædet både i de nationale samfund og i det internationale samfund. $O g$ så kom terrorangrebet af 11 . september 2001 og den efterfølgende 'krig' imod terror, som har sat de demokratiske retsstatsprincipper under pres både nationalt og internationalt, og som har skabt konfrontation mellem civilisationerne i stedet for dialog.

Terror som middel til at fremme politiske mål er karakteriseret ved at være rettet imod uskyldige civile, som ikke er part i den konflikt, for hvilken de er blevet ofre. Sådanne angreb, der rammer i flæng, skaber skræk i offentligheden og nødvendiggør et modsvar, nationalt og internationalt, der midlertidigt kan føre til suspension af sædvanlige retssikkerhedsgarantier i forbindelse med overvågning, ransagning $\mathrm{og} \mathrm{ad}-$ ministrativ tilbageholdelse ligesom regulær krigsførelse, hvor selve retten til livet ikke længere er garanteret, kan være påkrævet i nogle sammenhænge.

Den internationale retsorden har ikke kunnet dæmme op over for den trussel, som den internationale terrorisme udgør især som følge af den inhumane kampform, som disse terrorgrupper benytter. Og endnu en gang er det ikke regler, det skorter på.

Siden 1972 er det lykkedes inden for FN's rammer at vedtage en stribe af globale konventioner imod terrorisme, der kriminaliserer specifikke terrorhandlinger såsom gidseltagning, flykapring, skibskapring, terrorbombning, nuklear terrorisme, finansiering af terrorisme m.m. og tildeler staterne kompetence - såkaldt universel jurisdiktion - til at retsforfølge personer, der begår disse handlinger, uanset hvor i verden eller af hvem handlingen er begået. Under disse regelsæt er der tale om sædvanlig retsforfølgning i fredstid ved uafhængige nationale domstole med alle de retssikkerhedsgarantier dette indebærer. 
Hvor et terrornetværk som alQaeda betjener sig af organiserede kamphandlinger som 11. septemberangrebet til fremme af sine formål bevæger vi os over i krigens folkeret i bestræbelserne på at dæmme op over for denne kampform. Og her findes mere end 1000 detaljerede bestemmelser til regulering af staternes optræden under væbnede konflikter, hvad enten disse konflikter er lovlige eller ulovlige i henhold til FN-pagten.

Reglerne er bl.a. indeholdt i Haagerkrigsreglementet fra 1907, i de fire Genève-konventioner fra 1949 om beskyttelse af krigens ofre - de syge $o g$ sårede, civilbefolkningen og krigsfanger - samt i to tillægsprotokoller fra 1977, der bekræfter og udbygger de tidligere regelsæt gældende for henholdsvis internationale og interne væbnede konflikter. Jeg deltog selv i de mere end tre års diplomatiske forhandlinger i Genève, der førte til vedtagelsen af de to tillægsprotokoller. Opgaven var - og er at finde den rette balance mellem på den ene side, hvad den såkaldte militære nødvendighed kræver, og på den anden side de humanitære hensyn til de personer, der ikke - eller ikke længere - deltager i kamphandlingerne, i første række civilbefolkningen. I udformningen af disse regler er det de humanitære krav, der naturligt nok har fået overvægten. Det indebærer imidlertid, at staterne er omgærdet af humanitære regler i deres krigsoperationer i en sådan grad, at de gældende regler ofte overtrædes og dermed udstiller folkerettens afmagt, når det gælder kampen mod den internationale terrorisme.

\section{Status som kombattant}

Lad mig til illustration citere nogle af de grundlæggende regler. Den mest centrale lyder således:

"For at sikre respekten for og beskyttelse af civilbefolkningen og civile genstande, skal de stridende parter til enhver tid skelne mellem civilbefolkningen og kombattanter og mellem civile genstande og militære mål og skal i overensstemmelse hermed alene rette deres oprationer mod militære mål"

Herefter defineres militære mål, for så vidt angår genstande, som sådanne, der "ifølge deres natur, beliggenhed, formål eller anvendelse udgør et effektivt bidrag til en militær aktion og hvis fuldstændige eller delvise ødelæggelse, erobring eller neutralisering under de på det pågældende tidspunkt herskende omstændigheder udgør en klar militær fordel".

Hertil føjes, at det er forbudt at foretage et angreb, "som må forventes at medføre tilfældige tab af civilpersoners liv, skade på civile, ødelæggelse af civil genstande eller en kombination deraf, som betydeligt vil overstige den forventede konkrete og direkte militære fordel". Det er ikke let at være krigsførende, og 
det skal det vel heller ikke være, men det gøres i hvert fald ikke lettere, når modparten konsekvent undergraver disse regler ved at sløre den grundlæggende distinktion mellem civile og kombattanter. Og det er jo hvad de forskellige terrorgrupper netop gør - på trods af, at den folkeretlige krigsret bl.a. foreskriver, at det er en krigsforbrydelse at foregive civil status, når man i realiteten er kombattant, ligesom det er forbudt at benytte civilbefolkningen som skjold mod militære operationer.

Prøv at operere ud fra disse regler under den nylige væbnede konflikt i Gaza! Hvor langt kan man gå i beskyttelsen af en modstander, der ikke giver sig til kende som kombattant og dermed reelt bringer den almindelige civilbefolkning i fare under kamphandlinger?

Eller hvordan bekæmper man en selvmordsbomber forklædt i burka? Under diplomatkonferencen i Genève i 1970'erne forsøgte man at udvide beskyttelsen for guerrilla-kæmperen og nåede efter lange forhandlinger frem til følgende yderst imødekommende bestemmelse:

"For at $ø$ ge beskyttelsen af civilbefolkningen mod virkningen af fjendtlige handlinger, skal kombattanter kunne skelnes fra civilbefolkningen under et angreb eller under en militær operation forud for et angreb. I erkendelse af, at der er tilfælde under væbnede konflikter, hvor fjendtlighedernes karakter har til følge, at en bevæbnet kombattant ikke således kan skille sig ud, skal han dog bevare sin status som kombattant, forudsat at han i sådanne tilfælde bærer sine våben synligt under hvert enkelt militært engagement samt i det tidsrum, han er synlig for modparten, medens han er i færd med en militær deployering forud for iværksættelse af et angreb, hvori han skal deltage".

Næppe let at administrere i praksis, men afgørende for liv eller $\mathrm{d} \varnothing \mathrm{d}$, idet kombattant-status indebærer at man ikke kan straffes for selve det forhold at have taget del i kamphandlinger. I modsat fald er man at betragte som kriminel, der risikerer dødsstraf for sin deltagelse i kampen.

Retlige konstruktioner, der ikke afspejler de underliggende politiske realiteter kommer let til at eksistere alene på papiret. Det er samtidig klart, at staterne er bundet af deres påtagne humanitære forpligtelser uanset, at den ikke-statslige aktør som fx al-Qaeda og Taleban ikke formelt er deltagere i de folkeretlige regler på området. Repressalier mod beskyttede personer - krigsfanger og civile - er således forbudt. $\mathrm{Og}$ man skulle nødigt forfalde til modpartens inhumane optræden. Som Skarphedin udtrykker det i Njals Saga, da dødsfaren truer Njal og hans sønner: "Han bad dem ikke henfalde til klynk og klage, at ingen skulde få noget at sige dem på". "Thi af os," sagde han, "vil man ven- 
te mandigere adfærd end af andre, og det er kun som det skal være."

For indeværende kan folkeretten vist ikke yde mere til beskyttelse af ofrene for væbnede konflikter. Politisk dialog mellem civilisationerne må opgradueres. Eller som Mahatma Gandhi har udtrykt det: Hvis vold er den sidste udvej, så lad os i fællesskab ofre den næstsidste lidt mere opmærksomhed.

\section{Afsluttende synspunkt}

Inden man afskriver folkeretten som et tjenligt instrument til fremme af et fredeligt samarbejde mellem staterne, skal man erindre sig, at det typisk er den mere politisk prægede del af folkeretten vedrørende magtanvendelse og væbnede konflikter, der har svært ved at leve op til forventningerne. Det er naturligvis også et yderst centralt område, der berører selve staternes og borgernes eksistens og liv.

I den større sammenhæng må det imidlertid ikke glemmes, at folkeretten fungerer fuldt tilfredsstillende på en lang række centrale samlivsområder af praktisk karakter såsom kommunikation, sygdomsbekæmpelse, meteorologi, transport, patentbeskyttelse, uddannelse, arbej- derbeskyttelse, hvor arbejdet udføres i FN's mange særorganisationer (WHO, ILO, WMO, UNESCO, IMO, WIPO etc.). Disse regelsæt fungerer så godt som nogen national ret.

Jeg mener også, at vi har byggestene til de mere politisk prægede dele af folkeretten - hér mangler vi 'bare' den fælles politiske vilje til at realisere de mange idealistiske målsætninger, som er nedskrevet og godkendt af staterne. Allerede FN's verdenserklæring om menneskerettigheder fra 1948 indeholder opskriften til et solidarisk samfund med sin understregning af sociale fremskridt og højnelse af levevilkårene under samtidig respekt for det enkelte menneskes frihed og værdighed og med lige ret for mænd og kvinder.

Den internationale retsorden kan fra tid til anden komme under pres, men har efter min mening vokset sig tilstrækkelig robust til at modstå sådanne pres og fortsætte det lange seje træk til befæstelse af the rule of law-også i det internationale samfund.

\section{Ambassadør Tyge Lehmann er tidligere chef for Udenrigsministeriets juridiske tjeneste.}

